北海道大学 ${ }^{11}$ 、同 第 $\cdots$ 病理 ${ }^{21}$

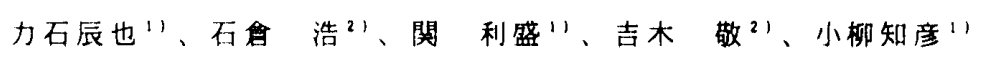

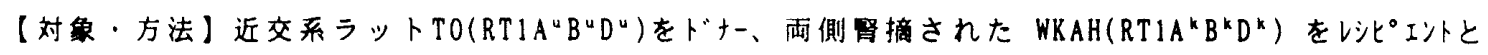
する堅移植を行い、非投与群とDSG 群 $(5 \mathrm{mg} / \mathrm{kg} / \mathrm{day}$ ，day 4 to 7)で生存日数を比较した。耐群の移 植瞥を経時的（day 4，6，8）に採取し、HE 染色、ICAM-1，LFA1，CLASS II，PCNAによる免疫組 織染色、DNA NICK END LABELING を行った。DSG 群で、移植䈐か生着しているWAKHに対し、WAKH，

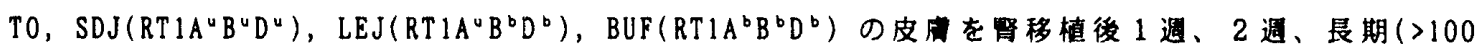
日）に移植し、寛容の状態を检討した。TOを stimulator，WKAHを responderとするMLRを行 い、長期生着WKAH の脾細胞を添加してその MLR 抑制能を検討した。【結果】非投与群の生着日

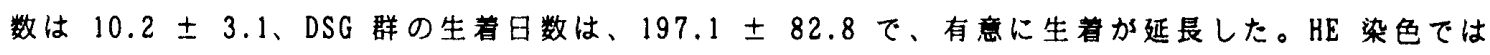
両群とも同程度のリンパ球浸潤を認めたか、DSG 群では、尿細管障害は艃微であった。ICAM-1，LF A1，CLASS II の浸濯リンバ球、尿細管上皮における発現は、雨群間に差はなかった。PCNAは、浸汪 リンバ球に関しては画群間に差はなかったか、DSG 群の尿細管で有意に発現が增強していた。DNAN ICK END LABELING 陽性浸閏リンパ球数は两群間に差はなかったか、DSG 群の尿細管は、非投与群に 比し、陽性細胞数は有意に少なかった。皮后移植では、腎移植後 1 遇では、WAKAH，T0，SDJ，の皮 届が生着したか、2週目以降では、WKAH、TOのみが生着した。MLRでは、長期生着WKAH の脾細胞 添加によってTO/WKAH の MLR は有意に抑制された。【考察】DSGはリンパ球の增殖、浸潤には影 霎を与えずに、発症後の急性挑絶反应を抑制し、泳細管はアポトーシスを免れていた。DSG 群では、移植

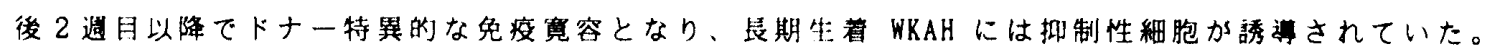

\title{
P-246 移植肾動脈病変におけるtenascinの動態
}

$$
\begin{aligned}
& \text { 大阪市大 }{ }^{11} \text { 、同第一病理 }{ }^{21} \text { 、吹田市民 }{ }^{31} \text { 、国立小児医庩研究センター4 }
\end{aligned}
$$

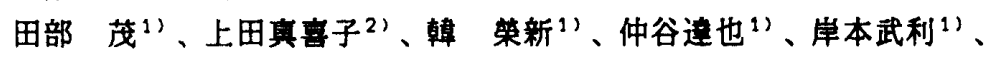

$$
\begin{aligned}
& \text { 柏原 型 }{ }^{31} 、 \text { 踰木盛-41、雨宮 浩 }{ }^{4}
\end{aligned}
$$

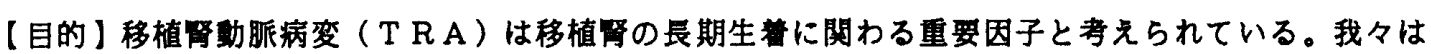
これまでの研究により、T RAの内膜増殖過程では、Tリンパ球およびマクロファージの集稘に引き続 き平滑筋細胞の遊走・增殖がもたらされることを示してきた。平滑筋細胞の遊走・増殖のメカニスムに ついては、末だ不明な点が多いが、最近種々の細胞外マトリックスの関与が示唆されている。Tenascin

（T N ）は細胞の避走・增殖・分化に関係する細胞外マトリックスの一つである.今回我々はヒト T R Aの進展過程におけるT Nの動態について兔疫組織化学的に検邻した。【対象】拒絶反応のため摘出さ

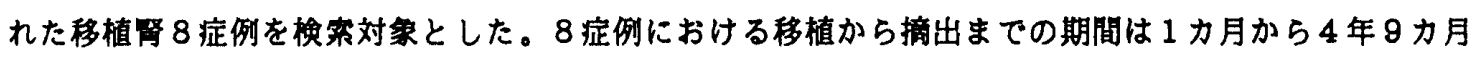

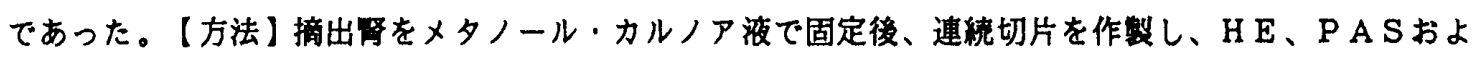
びエラスチカ・ワンギーソン染色を施行、病理組織学的に娭案した。残りの連続切片に対して、7 種の モノクローナル抗体（抗 T リンバ球抗体U C H L 1、抗Bリンバ球抗体L 26 、抗マクロファージ抗体 H A M 5 6、抗ビメンチン抗体、抗筋細胞アクチン抗体H H F 35 、抗平滑筋細胞アクチン抗体 C G A

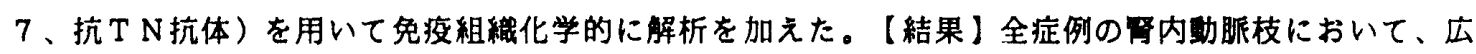
筑にT R A 認めた。移植後早期例（1〜3カ月）では、T RAの中膜にT Nの高度な発現がみられた か、新生内膜にはご軽度にしか発現していなかった。移植後 5 力月以降例では、新生内膜の一部に $\mathrm{T}$ $\mathrm{N}$ の発現がみられたか、、中膜での発現は陰性であった。【考察】以上より、ヒト移植晖における T R A の進展には、病初期におけるT Nのup-regulationの関与していることが強く示唆された。 